\title{
Functional and morphological modifications induced in rat islets by pentamidine and other diamidines in vitro
}

\author{
D. Boillot ${ }^{1}$, P.in't Veld ${ }^{4}$, P. Sai ${ }^{3}$, G. Feutren ${ }^{2}$, W. Gepts ${ }^{4}$ and R. Assan ${ }^{1}$ \\ ${ }^{1}$ Diabetes Department, Hôpital Bichat, ${ }^{2}$ INSERM U 25, Hôpital Necker, Paris, ${ }^{3}$ Ecole Vétérinaire, Nantes, France, and \\ ${ }^{4}$ Vrije Universiteit, Brussel, Belgium
}

Summary. The antiprotozoal drug pentamidine can be toxic to islet cells in vivo and in vitro. Rat islets were exposed to pentamidine (mesylate and isethionate salts) and six other structurally related diamidines. The $\beta$-cell response to arginine + theophylline was suppressed by pentamidine $\left(10^{-2} \mathrm{mmol} / \mathrm{l}\right)$ while the glucagon and somatostatin secretionspersisted. All diamidines tested suppressed the $\beta$-cell function, with a log-dose-response proportionality, the mesylate compound being more potent than pentamidine isethionate, and the lipophilic analogs more than the hydrosoluble diamidines. Electron microscopy revealed distinct morphological alterations in islets exposed to pentamidine, the intensity of these changes being dose- and time-dependent, and the $\beta$ cells more severely damaged than the non- $\beta$ cells. ${ }^{51} \mathrm{Cr}$-la- belled islet cells and RIN 5 F cells consistently appeared more sensitive to pentamidine cytotoxicity than rat fibroblasts, myeloma cells and hepatocytes. The pentamidine-induced suppression of $\beta$-cell function was not, in conditions tested, affected by the presence of nicotinamide and the hexose concentration in the medium. The kinetics of islet damage were slower than those of streptozotocin and alloxan-induced islet damage. The present study confirms that pentamidine is selectively toxic to islet $\beta$ cells, with some features distinct from the alloxan and streptozotocin toxicities to these cells. The mechanism of this process and its precipitating factors in vivo need clarification.

Key Words: Pentamidine, diamidines, experimental diabetes, insulin secretion, islet morphology.
Previous studies have suggested that the antiprotozoal drug, pentamidine, can be toxic to islet $\beta$ cells in vivo and in vitro $[1,2]$. In order to analyze this effect further, rat islets, rat insulinoma cells and various non-insular cell lines were exposed to pentamidine and then studied for either hormone release or the morphological consequences of this treatment. Six other diamidines structurally related to pentamidine were similarly studied. To approach the mechanism of pentamidine toxicity to $\beta$ cells, the potential protective effects of concomitant exposure to either nicotinamide or high hexose concentrations were also tested.

\section{Material and methods}

\section{Functional studies}

Islets were obtained by the collagenase method [3] from non-fasted male Wistar rats (200-250 g), distributed in the wells of Falcon microtest plates (Beckton-Dickinson, Rockville, Md., USA), each well containing five islets in $250 \mu \mathrm{l}$ of basal medium: MEM Eagle medium (Flow Laboratories, Rockville, Md., USA), supplemented with $10 \%$ fetal calf serum (FCS), glutamine $(2 \mathrm{mmol} / \mathrm{l})$, sodium pyruvate $(1 \mathrm{mmol} / \mathrm{l})$, non essential aminoacids $(0.814 \mathrm{mg} / 1)$, streptomycin $(100 \mu \mathrm{g} / \mathrm{ml})$ and penicillin $(100 \mu \mathrm{U} / \mathrm{ml})$. This basal medium, containing glucose $(5.5 \mathrm{mmol} / \mathrm{l})$ was equilibrated with $\mathrm{O}_{2}: \mathrm{CO}_{2}(95 \%: 5 \%)$, pH being 7.4 .

Pentamidine mesylate (Specia, Paris, France) was dissolved in MEM basal medium. Freshly isolated islets were exposed to pentamidine $1 \mathrm{mmol} / 1$ to $10^{-4} \mathrm{mmol} / 1$ for $1-18 \mathrm{~h}$ at $37^{\circ} \mathrm{C}$ under $\mathrm{O}_{2}: \mathrm{CO}_{2}$ (95\%:5\%) atmosphere.

At the end of the incubation period, the islets were washed twice and exposed to basal or stimulatory media $(250 \mu \mathrm{l} /$ well $)$ for $15 \mathrm{~min}$. The stimulatory medium consisted of basal MEM Eagle medium $+\mathrm{L}$ $(+)$ arginine $\mathrm{HCl}(20 \mathrm{mmol} / \mathrm{l})+$ theophylline $(5 \mathrm{mmol} / \mathrm{l})$. Supernatants were harvested and frozen at $-20^{\circ} \mathrm{C}$ until hormone determina- tions. Similar experiments werc conducted either in the absence of glucose during pentamidine incubation, or in the presence of glucose (16.5 mmol/l), or 3-0 methylglucose ( $16.5 \mathrm{mmol} / 1$, Sigma, St Louis, MO, USA), or nicotinamide ( $2 \mathrm{mmol} / 1$, Special, Paris, France). Six other diamidine preparations (kindly provided by Dr. S Squires, May and Baker, Dagenham, $U K$ ) were tested similarly: pentamidine isethionate, propamidine isethionate, dibromopropamidine isethionate, phenamidine isethionate, diamidino-diphenylamine-( $\mathbf{H C l})_{2}$ and stilbamidine isethionate. Sodium isethionate and sodium mesylate were also tested in parallel.

Insulin, glucagon and somatostatin were determined by radioimmunoassay [4] using charcoal for the separation of free and bound hormone [5]. Purified rat insulin (Novo, Copenhagen, Denmark), pork glucagon (Novo) and synthetic cyclic somatostatin (Clin Midi, Montpellier, France) were used as standards. The glucagon antiserum was the $30 \mathrm{~K}$ serum from Dr. R. Unger (Dallas, Tex., USA) and that used for somatostatin assay was a gift from Dr. J. Gerich (Rochester, Minn., USA). It was verified that pentamidine, when added to the radioimmunoassay incubation medium, did not interfere with the tracer-antibody binding. The interassay variation coefficients werc $5 \%$ (glucagon and somatostatin) and 10\% (insulin).

\section{Morphological studies}

Rat islets used for the release experiments described above were fixed at the end of the incubation period by the addition of $2 \%$ glutaraldehyde in sodium cacodylate $(0.1 \mathrm{~mol} / 1 ; \mathrm{pH} 7.4)$ to an equal volume of incubation medium containing 40 islets. The material was post-fixed in $1 \%$ osmium tetroxide for $60 \mathrm{~min}$, stained en-bloc with $0.1 \%$ uranyl acetate in $0.1 \mathrm{~mol} / 1$ acetate buffer (pH 5.0) and embedded in Araldite. Thin sections $(2 \mu \mathrm{m})$ were stained with lead citrate and examined in a Zeiss 9S electron microscope (Zeiss, Oberkochen, FRG).

\section{Cytotoxicity studies}

Trypan blue exclusion test. Control and test islets were exposed to a $0.5 \%$ solution of Trypan blue ( $\mathrm{Wt} / \mathrm{vol})$ in $\mathrm{NaCl}$ solution $(0.154 \mathrm{~mol} / \mathrm{l})$ for $1 \mathrm{~min}$ and then examined under a dissecting microscope $(\times 40)$ with episcopic light (Nikon SMZ2, Tokyo, Japan). 


\section{3
3
2
2}

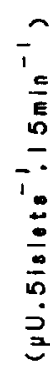

\section{CONTROL} ISLETS

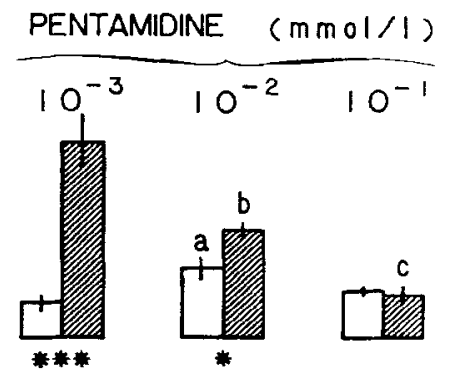

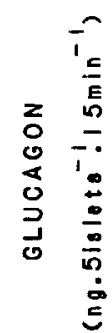
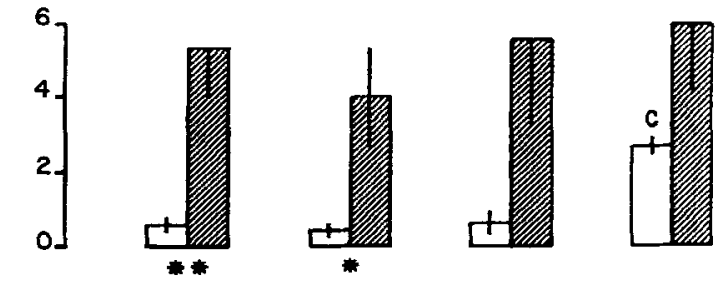

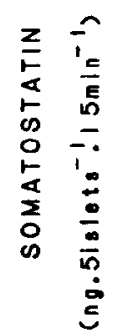
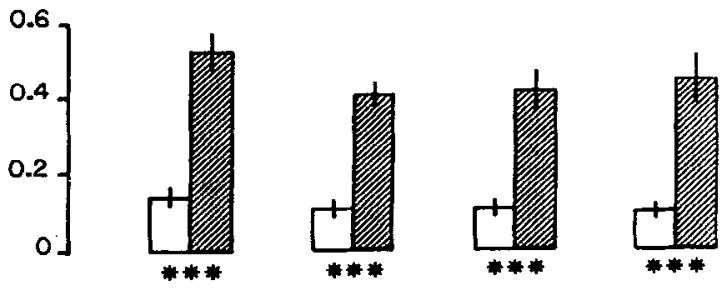

Fig. 1. Influence of pentamidine mesylate $10^{-3}$ to $10^{-1} \mathrm{mmol} / 1$ on the hormone secretions from normal rat islets exposed to the drug for $18 \mathrm{~h}$. $\square$ : basal hormone releases; $\square$ : secretion in a medium containing arginine $\mathrm{HCl}(20 \mathrm{mmol} / \mathrm{l})+$ Theophylline $(5 \mathrm{mmol} / \mathrm{l})$. Number of experiments was $8-12$ in all cases. Results are presented as mean \pm SEM. $* p<0.05 ; * * p<0.01 ; * * * p<0.001$ : statistical differences between basal and stimulated release; (a) $p<0.01$, (b) $p<0.01$, (c) $p<$ 0.001 : statistical differences between control and test islets, for the corresponding periods

${ }^{51}$ Chromium cytotoxicity test. Normal islet cells: rat islets were isolated by the collagenase technique [3] and dispersed islet cell suspensions were prepared by exposing islets to dispase (Boehringer, Mannheim, FRG) in calcium-magnesium-free medium [6]. Viability was estimated by the Trypan blue exclusion test; only suspensions with a least $90 \%$ viable cells were retained. Cells $\left(5 \times 10^{5}\right.$ in $1 \mathrm{ml} \mathrm{MEM}+15 \%$ FCS $)$ were incubated at $37^{\circ} \mathrm{C}$ for $1 \mathrm{~h}$ with $0.1 \mathrm{mCi} \mathrm{Na} 2{ }^{51} \mathrm{Cr} \mathrm{O}$ (CNTS, $\mathrm{Pa}$ ris, France), washed twice, distributed in Falcon microtest plates, each well containing $5 \times 10^{3}$ cells, and then incubated for $18 \mathrm{~h}$ in the presence of pentamidine $10^{-4}$ to $1 \mathrm{mmol} / \mathrm{l}$. The supernatants were counted in a gamma counter (Kontron MR 252, Kontron Analytic International, Zürich, Switzerland). ${ }^{51} \mathrm{Cr}$ release was compared with that of distilled water lysed cells.

RIN $5 \mathrm{~F}$ rat insulinoma cells: this cell line was kindly provided by Dr. Chick (University of Massachusetts Worcester, Mash., USA) [7]. Monolayer cultures were incubated with trypsin $0.024 \%$ in isotonic phosphate buffer, pH 7.4. After centrifugation, cells were resuspended in RPMI 1640 (Flow Laboratories, Rockwille, Md., USA) containing $10 \%$ (vol/vol) FCS, at a concentration of $10^{5}$ cells $/ \mathrm{ml}$. Suspension (100 $\mu$ i) was distributed into each well of Falcon microtest plates and cultured for $25 \mathrm{~h}$. Supernatants were discarded and replaced by $\mathrm{RPMI}+\mathrm{FCS}$ containing $\mathrm{Na}_{2}{ }^{51} \mathrm{Cr} \mathrm{O}_{4}(0.06 \mu \mathrm{Ci} /$ well) [8]. Four hours later, preparations were washed three times and exposed to pentamidine in RPMI + FCS for $18 \mathrm{~h}$. Supernatants were counted and the results were calculated as above.

Fetal rat fibroplasts: fibroblasts obtained from 20-day-old mouse fetuses were cultured for 3 weeks [9], treated with trypsin for $10 \mathrm{~min}$ at $37^{\circ} \mathrm{C}$, resuspended in MEM at a concentration of $10^{6} \mathrm{cells} / \mathrm{ml}$. Five
Table 1. B-cell response to $\mathrm{L}(+)$ arginine $(20 \mathrm{mmol} / 1)+$ theophylline $(5 \mathrm{mmol} / \mathrm{l})$ from rat islets incubated for $18 \mathrm{~h}$ in the absence of pentamidine (control islets) or in the presence of pentamidine mesylate $\left(10^{-1} \mathrm{mmol} / 1\right)$.

\begin{tabular}{|c|c|c|}
\hline & $\begin{array}{l}\text { Basal-insulin } \\
\text { release } \\
\text { ( } \mu \mathrm{U} .5 \text { islets } \\
{ }^{-1} .15 \mathrm{~min}^{-1} \text { ) }\end{array}$ & $\begin{array}{l}\text { Stimulated-in- } \\
\text { sulin release } \\
\text { ( } \mu U .5 \text { islets } \\
-1.15 \mathrm{~min}^{-1} \text { ) }\end{array}$ \\
\hline Control islets & $200 \pm 40$ & $1082 \pm 90$ \\
\hline Pentamidine $\left(10^{-1} \mathrm{mmol} / 1\right)$ & $259 \pm 21$ & $234 \pm 43(\mathrm{c})$ \\
\hline Glucose $(16.5 \mathrm{mmol} / 1)$ & $519 \pm 47(b)$ & $824 \pm 72$ \\
\hline Pentamidine + glucose & $214 \pm 30$ & $200 \pm 39(\mathrm{c})$ \\
\hline 3-0-methyl-glucose $(20.5 \mathrm{mmol} / 1)$ & $240 \pm 80$ & $1208 \pm 28$ \\
\hline Pentamidine $+3-0$-methyl-glucose & $490 \pm 100$ (a) & $525 \pm 135(\mathrm{~b})$ \\
\hline Nicotinamide $(2 \mathrm{mmol} / \mathrm{l})$ & $300 \pm 90$ & $1430 \pm 160$ \\
\hline Pentamidine + nicotinamide & $340 \pm 35$ & $320 \pm 40(b)$ \\
\hline Glucose-free medium & $210 \pm 23$ & $403 \pm 63(b)$ \\
\hline Pentamidine + glucose-free medium & $196 \pm 12$ & $215 \pm 17(\mathrm{c})$ \\
\hline
\end{tabular}

Incubation medium contained glucose $(5.5 \mathrm{mmol} / \mathrm{l})$ unless otherwise mentioned. Results are presented as mean \pm SEM, number of experiments was $6-12$ in each group.

${ }^{\mathrm{a}} p<0.01 ;{ }^{\mathrm{b}} p<0.005 ;{ }^{\mathrm{c}} p<0.001$ for statistical differences from corresponding control values

hundred $\mu \mathrm{l}$ of this suspension plus $1 \mathrm{ml}$ MEM were incubated with $0.1 \mathrm{mCi} \mathrm{Na}_{2}^{51} \mathrm{CrO}_{4}$ for $1 \mathrm{~h}$ at $37^{\circ} \mathrm{C}$, washed twice and then re-incubated in Falcon microtest plates ( 5000 cells/well) in the presence of pentamidine 1 to $10^{-4} \mathrm{mmol} / 1$ for $18 \mathrm{~h}$. Supernatants were counted and results calculated as above.

Rat myeloma cells: the IR 983-F cell line was kindly provided by H. Bazin (Brussels, Belgium) [10]; cells were labelled with ${ }^{51} \mathrm{Cr}$, incubated in the presence of pentamidine and the supernatants were counted as described above for the other cell lines.

Hepatocyte cytotoxicity assay: this was performed according to a method described previously [11]. Hepatocytes from Wistar rats were isolated by portal perfusion of collagenase $(0.02 \%$, II type, Worthington, Freehold, New Jersey) [12]; their initial viability tested by a Trypan blue staining was $85 \%$. The hepatocyte suspension in RPMI $1640+$ Hepes $(10 \mathrm{mmol} / 1), 10 \% \mathrm{FCS}$, glutamine $(2 \mathrm{mmol} / 1)$, streptomycin $(100 \mu \mathrm{g} / \mathrm{ml})$ and penicillin $(100 \mu \mathrm{U} / \mathrm{ml})$ (Gibco, Paisley, UK) was distributed on Falcon microtest plates $(20000$ cells $/$ well $)$ in $0.1 \mathrm{ml}$ and incubated for $18 \mathrm{~h}$ at $37^{\circ} \mathrm{C}$ under an air- $\mathrm{CO}_{2}$ atmosphere in presence of various concentrations of pentamidine or medium alone. Supernatants were then harvested for aspartate aminotransferase (ASAT) detcrmination. Enzyme activity was assayed by a kinetic method using an automated centrifugal analyzer (Cobas-Bio, Roche, Neuilly-sur-Seine, France) and TGO-kit (Biomérieux, L'Arbresle, France). Percentage of ASAT release was compared with that of hepatocytes lysed by Triton X 100 (Sigma, St Louis, Mo., USA), 0.05\% in water.

\section{Statistical analysis}

Results are expressed as mean \pm SEM. Statistical significance of differences was analyzed by using the Student's t-test for non-paired values.

\section{Results}

\section{Functional studies}

Exposure of normal rat islets to pentamidine mesylate $10^{-2}$ and $10^{-1} \mathrm{mmol} / 1$ suppressed the $\beta$-cell response to arginine + theophylline, but not that of $A$ and $D$ cells (Fig. 1). In the presence of pentamidine $10^{-1} \mathrm{mmol} / \mathrm{l}$, the basal glucagon release was higher than control values $(p<0.001)$. In these experiments, the selective sup- 


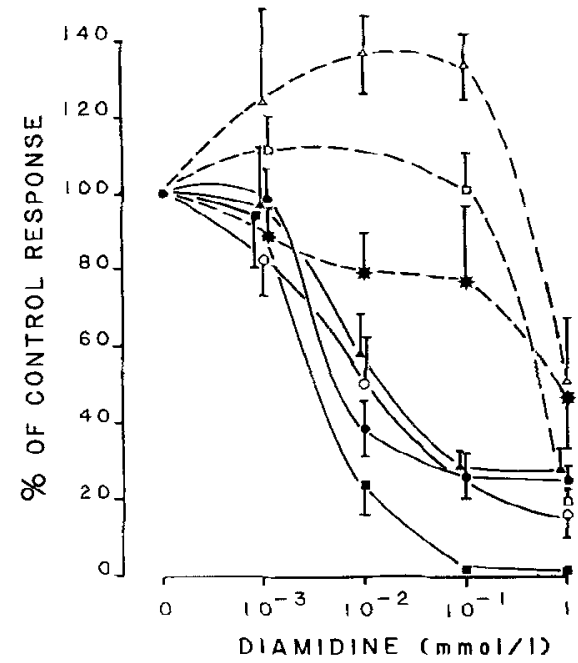

Fig. 2. Influence of seven diamidine preparations on the $P$-cell response from rat islets incubated in vitro. The 100\% response corresponded to control rat islets incubated for $18 \mathrm{~h}$ in basal medium (pentamidine-free) and then stimulated by arginine $(200 \mathrm{mmol} / \mathrm{l})+$ theophylline $(5 \mathrm{mmol} / 1)$ for $15 \mathrm{~min}$. Test islets were exposed to diamidines for $18 \mathrm{~h}$ before stimulation: ( $)$ pentamidine mesylate; (O) pentamidine isethionate; $(O)$ propamidine isethionate; $(\Delta)$ dibromopropamidine isethionate; $(\Delta)$ phenamidine isethionate; (*) diamidino-diphenylamine $(\mathrm{HCl})_{2} ;(\square)$ stilbamidine isethionate. Results are expressed as mean $\pm S E M$; the number of experiments was six in each case

Table 2. Influence of sodium isethionate on the basal and stimulated insulin release from rat islets stimulation was induced by arginine $(20 \mathrm{mmol} / 1)$ theophylline $(5 \mathrm{mmol} / 1)$ (see text for experimental details)

\begin{tabular}{llr}
\hline & $\begin{array}{l}\text { Basal } \\
\text { insulin } \\
\text { release }\end{array}$ & $\begin{array}{l}\text { Stimulated } \\
\text { insulin } \\
\text { release }\end{array}$ \\
\cline { 2 - 3 } & \multicolumn{1}{l}{$\left(\mu \mathrm{U} .5\right.$ islets $\left.^{-1} .15 \mathrm{~min}^{-1}\right)$} \\
\hline Control islets & $200 \pm 38$ & $1042 \pm 42$ \\
+ Sodium isethionate $\left(10^{-4} \mathrm{mmol} / 1\right)$ & $220 \pm 27$ & $1066 \pm 30$ \\
+ Sodium isethionate $\left(10^{-3} \mathrm{mmol} / 1\right)$ & $172 \pm 32$ & $991 \pm 36$ \\
+ Sodium isethionate $\left(10^{-2} \mathrm{mmol} / 1\right)$ & $132 \pm 28$ & $984 \pm 20$ \\
+ Sodium isethionate $\left(10^{-1} \mathrm{mmol} / 1\right)$ & $185 \pm 36$ & $937 \pm 42$ \\
+ Sodium isethionate $(1 \mathrm{mmol} / \mathrm{l})$ & $209 \pm 27$ & $1042 \pm 25$ \\
\hline
\end{tabular}

Number of experiments was 6 in each group

pression of the $\beta$-cell response to the stimulus was affected by neither the omission of glucose from the pentamidine incubation medium, nor the addition of glucose $(16.5 \mathrm{mmol} / \mathrm{l}), 3-0$ methylglucose $(16.5 \mathrm{mmol} / \mathrm{l})$ and nicotinamide ( $2 \mathrm{mmol} / \mathrm{l})$ (Table 1 ). But the basal release in the presence of 3-0 methylglucose + pentamidine was increased, for some undetected reason.

Pentamidine isethionate and the other six diamidines also suppressed the $\beta$-cell response to arginine + theophylline. Calculation of the dose response curves suggested some differences in activity for these drugs in the $10^{-2}$ to $1 \mathrm{mmol} / 1$ concentration range (Fig. 2). Pentamidine mesylate was the most active compound, followed by propamidine and dibropropamidine, then by pentamidine isethionate. Stilbamidine, phenamidine and diamidino-diphenylamine were the less active drugs.

Sodium isethionate had no influence on the $\beta$ cell responses to arginine + theophylline (Table 2).

\section{Morphological studies}

Electron microscopic examination revealed distinct morphological alterations at the cellular level in islets exposed to pentamidine; the intensity of these changes was time- and dose-dependent. After $12-18 \mathrm{~h}$ of exposure, pentamidine $10^{-1} \mathrm{mmol} / \mathrm{l}$ resulted in necrosis of most endocrine cells. All $\beta$ cells were necrotic (Fig. 3 a), while some A cells at the islet periphery remained intact but severely damaged with vesiculated and dilated cisternae of the rough endoplasmic reticulum. A shorter exposure time $(2 \mathrm{~h})$ resulted in swelling of the $\beta$-cell rough endoplasmic reticulum cisternae (Fig. 3 b); there was no noticeable effect on the non- $\beta$ cells. In the islets exposed to pentamidine $10^{-2} \mathrm{mmol} / \mathrm{l}(18 \mathrm{~h})$ most $\beta$ cells were damaged, their cytoplasm containing large vacuoles derived from the rough endoplasmic reticulum (Fig. $3 \mathrm{c}$ ). These cells were almost completely degranulated, while non- $\beta$ cells showed no evident signs of cell damage or degranulation (Fig. $3 \mathrm{c}$ ). After exposure for $18 \mathrm{~h}$ to pentamidine $10^{-3} \mathrm{mmol} / 1$, islet cells showed no distinct morphological changes when compared with control material (Fig. 3 e and $3 \mathrm{f}$ ).

\section{Cytotoxicity studies}

Exposure to pentamidine for $18 \mathrm{~h}$ was toxic to the ${ }^{51} \mathrm{Cr}$ labelled islet cells and RIN $5 \mathrm{~F}$ cells at concentrations of $10^{-4}$ to $1 \mathrm{mmol} / 1$ while fibroblasts and myeloma cells were damaged only at the highest pentamidine concentration tested of $1 \mathrm{mmol} / 1$ and the rat hepatocytes at concentration of $10^{-1}$ to $1 \mathrm{mmol} / \mathrm{l}$ (Table 3 ).

After addition of the Trypan blue solution, the dark blue islets were, in all instances, easily distinguishable from the bright white islets. One half of the islets was stained after $5 \mathrm{~h}$ in the presence of pentamidine $10^{-1} \mathrm{mmol} / \mathrm{l}$, while similar half maximal damage was reached within $30 \mathrm{~min}$ in case of alloxan, and $70 \mathrm{~min}$ in the presence of streptozotocin at same molar concentrations (Fig. 4).

\section{Discussion}

These results confirm and expand some previous [1, 2] observations: (1) pentamidine altered selectively insulin release and $\beta$-cell response to arginine + theophylline, while $A$ and D cell responses were not suppressed; (2) six other diamidines structurally related to pentamidine also suppressed $\beta$-cell function with a dose-dependent proportionality; (3) morphological evidence of islet cell damage was observed with a similar dose- and time-dependency; (4) non- $\beta$ cells and some extrainsular cell lines appeared less sensitive than were $\beta$ cells to the drug; (5) the kinetics of islet necrosis, as assessed by Trypan blue exclusion, were slower in case of pentamidine than in the presence of alloxan, or streptozotocin; and (6) no clear protective effect of nicotinamide and high hexose concentrations was detected under these experimental conditions.

The hypothesis of pentamidine toxicity to $\beta$ cells originated from clinical observations of patients who presented hypoglycaemia, then diabetes mellitus, fol- 


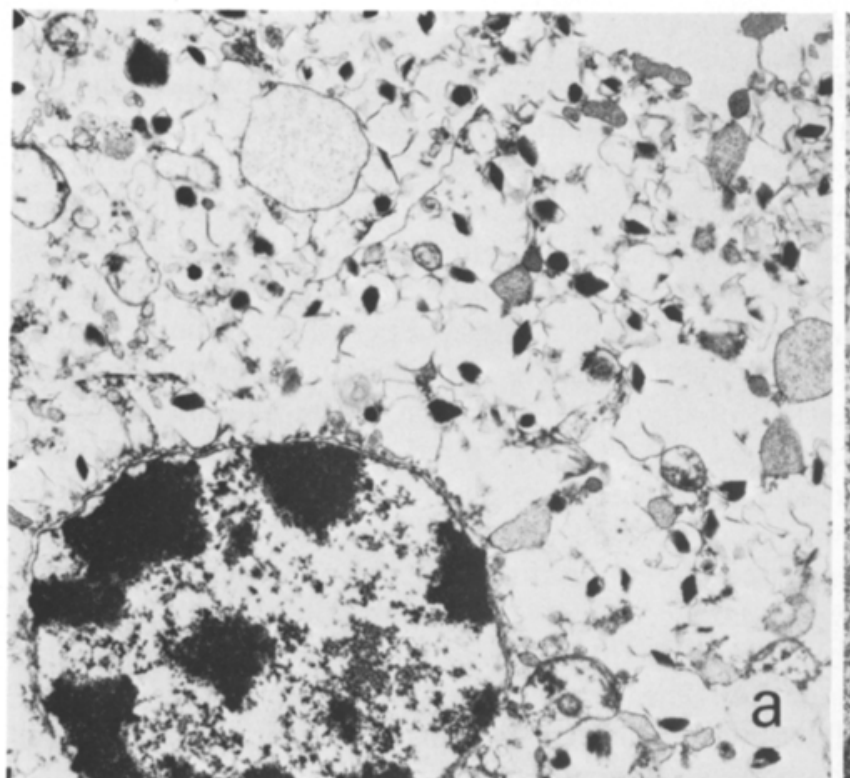

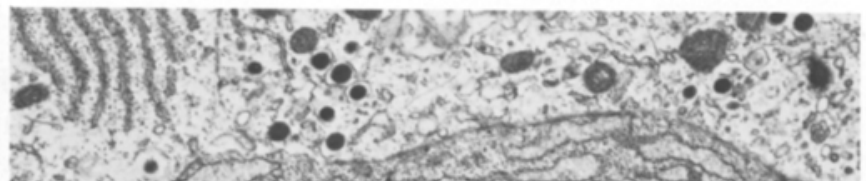

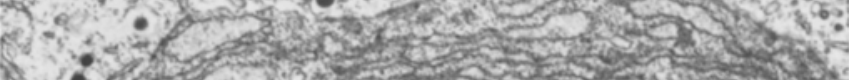

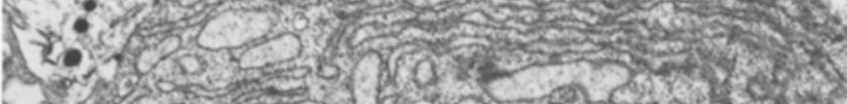

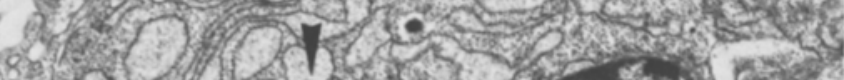
75- 30 -

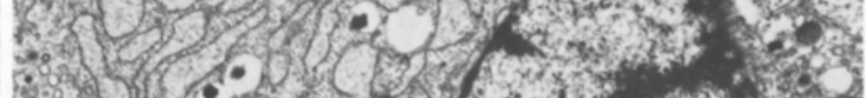

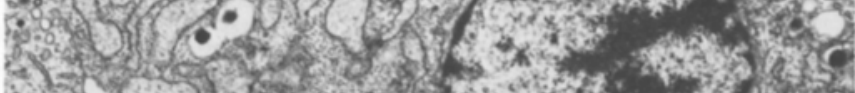
s.c.

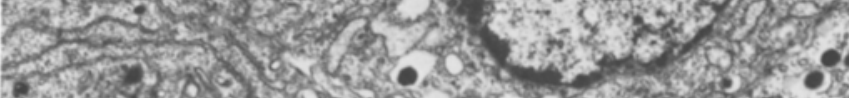

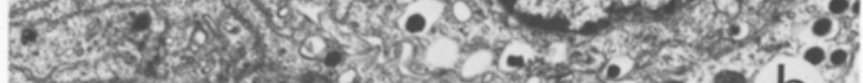
bit.

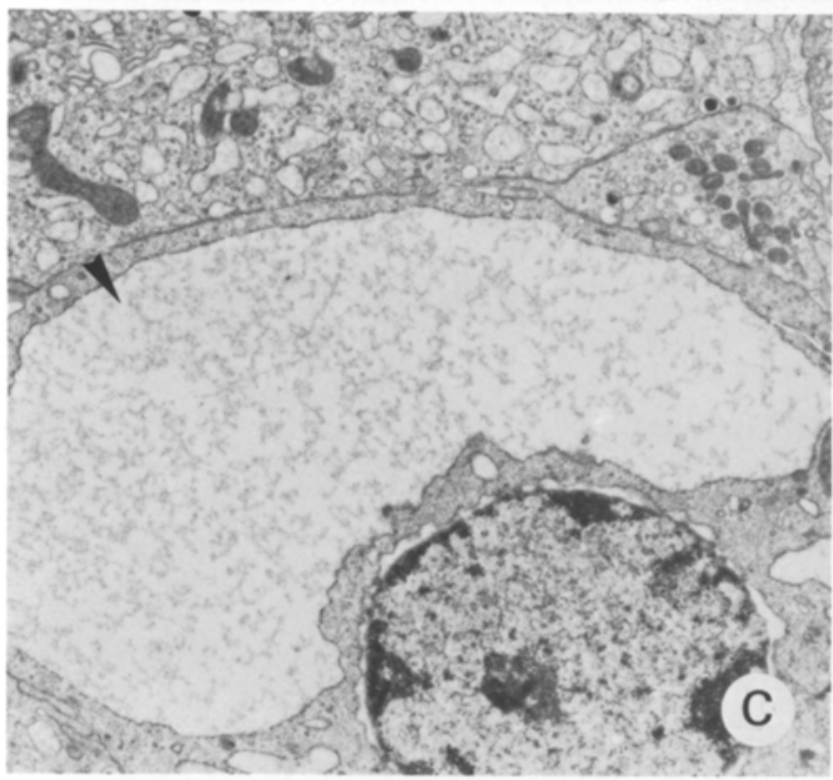

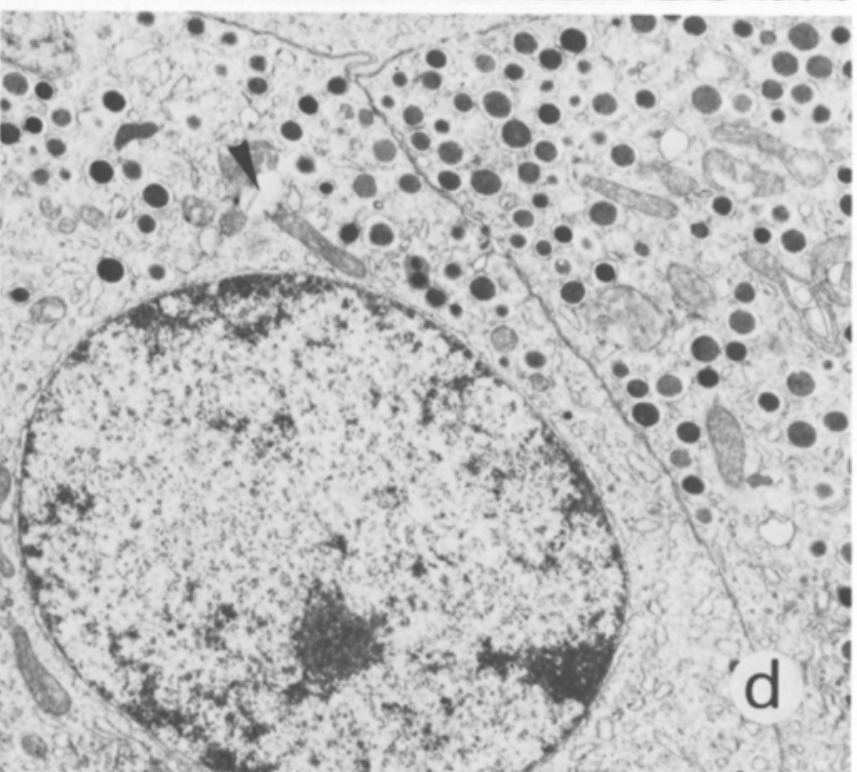
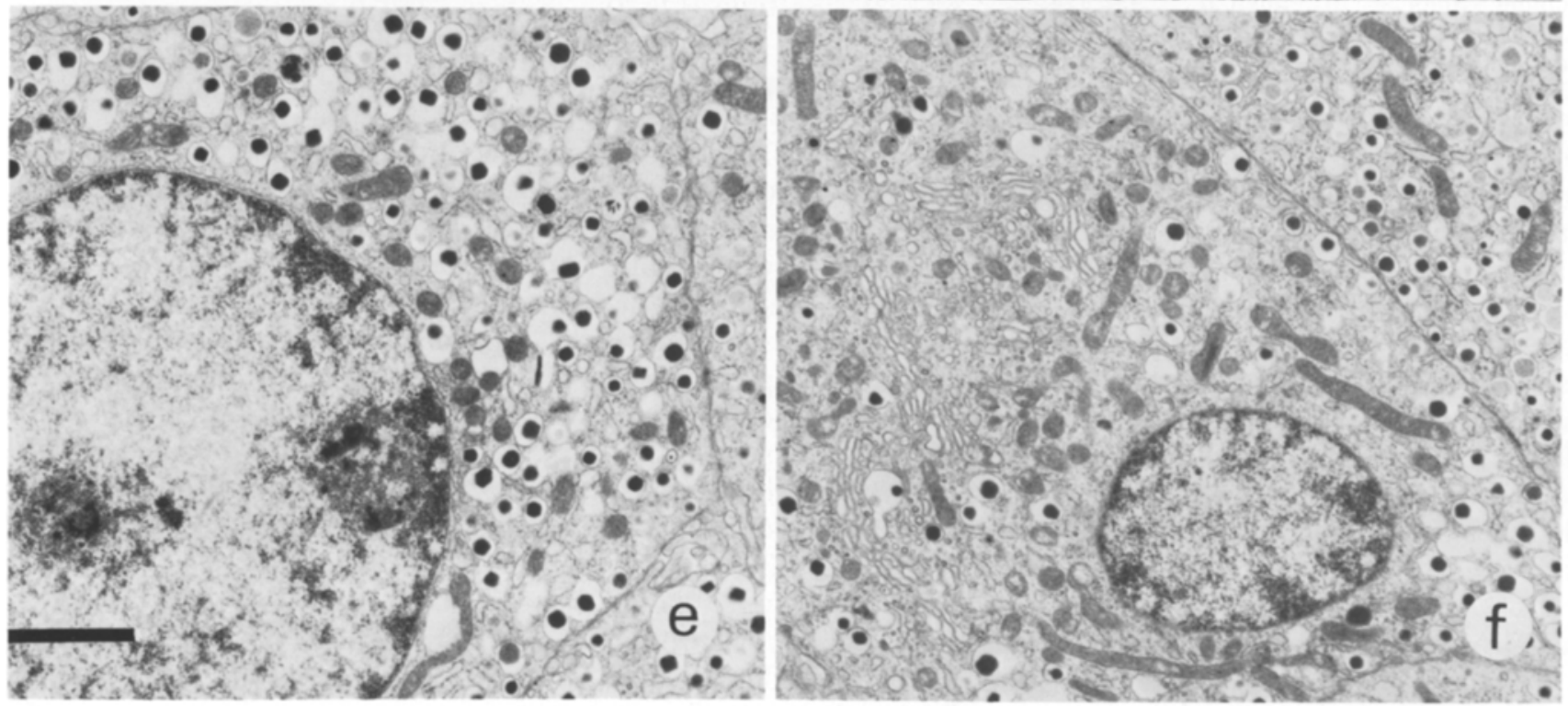
Table 3. Pentamidine toxicity to various cell lines in vitro

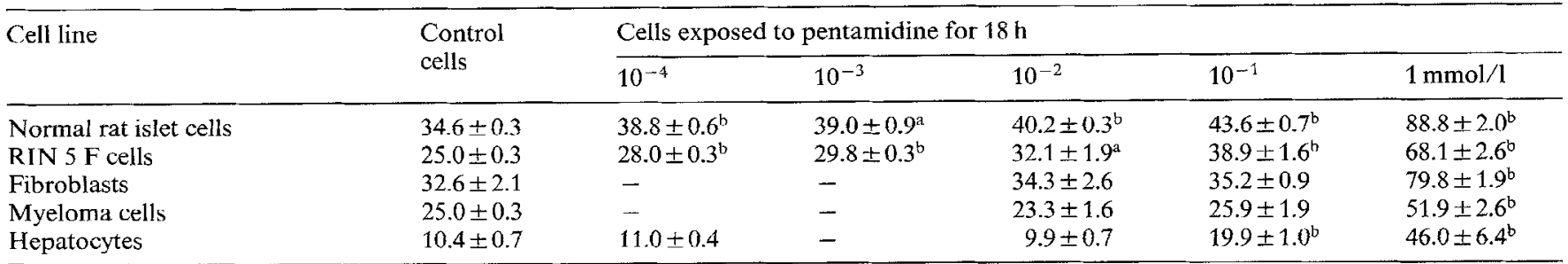

Results are expressed either in perccntage of total ${ }^{51} \mathrm{Cr}$ release from distilled water lysed cells (islet cells, RIN $5 \mathrm{~F}$ cells, fibroblasts, myeloma cclls) or in percentage of aspartate aminotransferase units from Triton lysed hepatocytes. Results are presented as mean \pm SEM; number of experiments was $5-8$ in each group; ${ }^{a} p<0.01 ;{ }^{b} p<0.001$ : statistical differences from corresponding control values

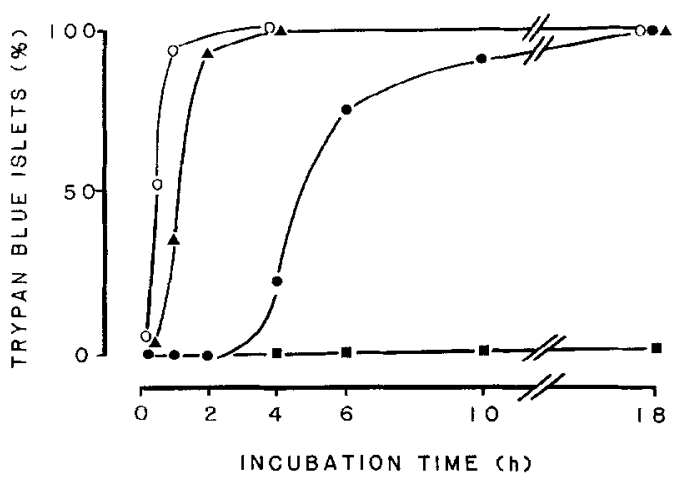

Fig. 4. Percentage of Trypan blue positive islets following exposure to pentamidine $10^{-1} \mathrm{mmol} / 1(\bullet)$, alloxan $(\mathrm{O})$, and streptozotocin $(\Delta)$ at same molar concentration, and control islets ( $)$; 40 islets were analyzed each time

lowing treatment by pentamidine of Pneumocystis carinii pneumonitis [1]. This pulmonary complication occurs frequently in immunodepressed patients and pentamidine preparations are widely used for its treatment. In the United States, the number of patients treated with pentamidine has increased from 118 in 1980 to 1474 in 1983, and reached 2546 for the 10 first months of 1984 (Dr. T. R. Navin, Center of Infectious Diseases, Atlanta, Ga, USA, personal communication). For the last 424 patients treated under control of this center, 10 were reported to have hypoglycaemia severe enough to require repeated doses of $50 \%$ glucose and another 15 were reported to have moderate hypoglycaemia. As regards diabetes mellitus, 12 new cases have been recently added in 1984 [13] to the 29 others previously reported [1]. On the other hand, the number of patients with try-

Fig. 3a-f. Electron micrographs of rat islet cells exposed to pentamidine. a Necrosis induced by an 18 - $h$ exposure to pentamidine $10^{-1}$ $\mathrm{mmol} / \mathrm{l} ; \mathrm{b} \beta$ cell from an islet exposed for $2 \mathrm{~h}$ to the same pentamidine concentration as in a; RER cisternae (arrowhead) are swollen and contain material of moderate electron density; $\mathrm{c}$ effect of 18 -h exposure to pentamidine $10^{-2} \mathrm{mml} / 1$ on $\beta$-cell RER-cisternae, which are strongly dilated and form large vacuoles (arrowhead) containing some flocculent material; most $\beta$ cells are degranulated; d A cell exposed to pentamidine $10^{-2} \mathrm{mml} / 1$ (18 h) showing no evident sign of cell damage; the small vacuoles inside the mitochondria (arrowhead) are also occasionally present in the pentamidine-treated matcrial though their quantity may be larger in the pentamidine-treated material; $\mathbf{e} \beta$ cell exposed to pentamidine $10^{-3} \mathrm{mml} / 1(18 \mathrm{~h})$; its morphology is not notably different from that of the control material. Magnification: X $7500 /$ Bar $2 \mu \mathrm{m}$ panosomiasis, liable to be treated with pentamidine, keeps increasing [14]. A precise knowledge of pentamidine toxicity is therefore clinically relevant. Pentamidine mesylate may be more toxic to $\beta$ cells in vivo than pentamidine isethionate [15], a suggestion consistent with our present data.

The demonstration of morphological islet damage and that of a selective toxicity to $\beta$ cells are major steps in the description of this toxic effect. Lysis of $\beta$ cells by pentamidine had been postulated, to account for the early hypoglycaemic attacks associated with inappropriately high insulinaemia, in pentamidine-treated subjects. This is consistent with: (1) the higher-than-normal basal insulin release from islets exposed to pentamidine and (2) the results of ${ }^{51} \mathrm{Cr}$ release and Trypan blue exclusion tests. The mechanism of pentamidine toxicity to islet $\beta$ cells at a cellular and molecular level remains unclear. Pentamidine is a lipophilic molecule: this favours rapid transfer across plasma membranes. Pentamidine rapidly disappears from the bloodstream [16]. Among the six diamidine molecules tested, those which were the most toxic to islets contained an aliphatic (lipophilic) chain linking the two phenolic groups, and the toxicity was proportionate to the length of this chain. It has been suggested that the carbon chain served primarily as a carrier for the strongly basic active amidine group, and then further explorations led to the synthesis of diamidines containing aromatic groups as carriers [17]. On the other hand, pentamidine is highly cationic and this may favour a selective uptake by the $\beta$ cell granules, the operationally defined $\mathrm{pH}$ of which is acid [18-20]. A rapid uptake of pentamidine by islet cells is strongly suggested by parallel experiments where purified $\beta$ cells showed structural damage after incubation periods of 15 min (D. Pipeleers, unpublished observations).

Following the uptake of the drug by islet cells, the toxicity may develop slowly, differing in that from alloxan and streptozotocin (Fig. 4). Pentamidine can bind to nucleosides from nucleic acids, ATP and ADP in vitro [21]. This observation is consistent with the previous demonstration that pentamidine interferes with DNA, RNA and protein synthesis $[22,23]$ and inhibits thymidylate synthetase [24]. No protective effect of high glucose or nicotinamide concentrations on the $\beta$-cell function was observed in the present experimental sets, although some protection may exist for shorter exposure times, as regards cytotoxicity (D. Pipeleers, unpublished observations). An alloxan-like mechanism of action 
cannot be excluded. The breakdown products of the diamidines and guanidines include xanthine and uric acid, which are chemically close to alloxan [25]. Pentamidine catabolism may lead to alloxan-related compounds, but most studies suggest that pentamidine is not metabolized in vivo [16, 26] and its mechanism of toxicity may differ from that of alloxan. Further studies on the potential protective effect of free radical scavengers are needed [27-30]. Since the inhibitory effect of sodium isethionate upon insulin release is rapidly reversible $[31,32]$ it cannot account for the irreversible effect of pentamidine isethionate.

The pentamidine toxicity to insulinoma cells may be of potential therapeutic value. Recently pentamidine has been shown to lyse human insulinoma in vitro [33], consistently with present observation on RIN $5 \mathrm{~F}$ cells. However, no beneficial effect was obtained in vivo in one patient and no experimental model of pentamidineinduced diabetes in vivo is available to date. Further work is needed to clarify the conditions of pentamidine toxicity to normal and tumour islet tissue in vivo.

Acknowledgments. We wish to express our gratitude to the following: Drs. S.Squires, J.Gerich, R. Unger, W.L.Chick and H. Bazin. Drs. D. Pipeleers and P. Halban contributed to helpful and stimulating discussions. Dr. T. R. Navin provided important informations on the distribution of pentamidine by the Centers of Disease Control (Atlanta, GA). We thank for invaluable technical help: Mrs. H. Cohen, C. Maurel, L. Corail. This work was supported by a grant from UER Xavier Bichat (Paris VII).

\section{References}

1. Bouchard Ph, Sai P, Reach G, Caubarrere I, Ganeval D, Assan R (1982) Diabetes mellitus following pentamidine-induced hypoglycemia in humans. Diabetes 31: 40-45

2. Sai P, Boillot D, Boitard Ch, Debray-Sachs M, Reach G, Assan R (1983) Pentamidine, a new diabetogenic drug in laboratory rodents. Diabetologia 25: 418-423

3. Lacy PE, Kostianovsky M (1967) Method for the isolation of intact islets of Langerhans from the rat pancreas. Diabetes 16:35-39

4. Yalow RS, Berson SA (1960) Immunoassay of endogenous plasma insulin in man. $\mathbf{J}$ Clin Invest 39: 1157-1166

5. Herbert V, Lau KS, Gottlieb CV, Bleicher S (1965) Coated charcoal immunoassay of insulin. J Clin Endocrinol Metab 25: 1375-1380

6. Boitard Ch, Debray-Sachs M, Pouplard A, Assan R, Hamburger J (1981) Lymphocytes from diabetics suppress insulin release in vitro. Diabetologia 21: 41-46

7. Gazdar AF, Chick WL, Oie HK, Sims HL, King DL, Weir GG, Lauris V (1980) Continuous clonal insulin and somatostatin secreting cell lines established from a transplantable rat islet cell tumor. Proc Natl Acad Sci USA 77: 3523-3529

8. Eisenbarth GS, Morris MA, Scearce RM (1981) Cytotoxic antibodies to cloned rat islet cells in serum of patients with diabetes mellitus. J Clin Invest 67: 403-408

9. Hellström I, Hellström KE (1971) In: Bloom BB, Glade PR (eds) In vitro methods in cell-mediated immunity. Academic Press, New York, pp 409-414

10. Bazin $H$ (1981) Production of rat monoclonal antibodies with the Lou rat non secreting IR 983 F myeloma cell line. In: Peeters H (ed) Protides of the biological fluids. Proceedings of 29th colloquium, Brussels. Pergamon, Oxford New York Paris

11. Feutren $G$, Lacour B (1983) Une méthode simple et précise de mesure de mortalité des hépatocytes en culture: le pourcentage de relargage de l'aspartate aminotransférase. Gastroenterol Clin Biol 7: $104 \mathrm{~A}$

12. Seglen PO (1976) Preparation of isolated rat liver cells. Meth Cell Biol 13: 79-83

13. Jha TK, Sharma VK (1984) Pentamidine-induced diabetes mellitus. Trans Royal Soc Trop Med Hyg 78: 252-253

14. Ginoux PY, Lancien P, Frezil JL, Bissadidi N (1984) Failures in the treatment of $\mathrm{T}$. gambiense trypanosomiasis in the Congo Med Trop 44: 149-154

15. Belehu A, Naafs B (1982) Diabetes mellitus associated with pentamidine mesylate. Lancet 1: 1463-1464

16. Waalkes TP, Denham C, Devita VT (1970) Pentamidine: clinical pharmacologic correlations in man and mice. Clin Pharmacol Ther 11: 505-512

17. Schoenbach EB, Greenspan EM (1948) The pharmacology, mode of action and therapeutic potentialities of stilbamidine, propamidine and other aromatic diamidines. Medicine 27:327-377

18. Täljedal IB (1981) On insulin secretion. Diabetologia 21: 1-17

19. Sehlin J, Lindström P (1984) Increased cell pH stimulates insulin release. Diabetologia 27:331 A

20. Wollheim SB, Ullrich SJ, Salomon DC, Halban PA, Tsien RY, Pozzan T (1984) Lack of correlation between nutrient-induced changes of cytosolic $\mathrm{pH}$ and insulin release. Diabetologia 27 : $347 \mathrm{~A}$

21. Makulu DR, Waalkes TP (1975) Interaction between aromatic diamidines and nucleic acids: possible implications for chemotherapy. J Natl Cancer Inst 54: 305-309

22. Pesanti EL, Cox C (1981) Metabolic and synthetic activities of pneumocystis carinii in vitro. Infect Immun 34: 908-914

23. Bornstein RS, Yarbro JW (1970) An evaluation of the mechanism of action of pentamidine isethionate. J Surg Oncol 2: 393-398

24. Kaplan HG, Myers CE (1977) Complex inhibition of thymidilate synthetase by aromatic diamidines: evidence for both rapid, freely reversible and slowly progressive, non-equilibrium, inhibition. J Pharmacol Exp Therapeutics 261: 554-563

25. Bryceson A (1968) Pentamidine-induced diabetes mellitus. East Afr Med J 45: 111-117

26. Asghar SS (1976) Diphenyl-diamidines: a theoretical evaluation of their possible therapeutical uses. J Molec Med 2: 1-24

27. Fischer LJ, Hamburger SA (1980) Inhibition of alloxan action in isolated pancreatic islets by superoxide dismutase, catalase and a metal chelator. Diabetes 29:213-216

28. Sandler S, Andersson A (1982) The partial protective effect of the hydroxyl radical scavenger dimethyl urea on streptozotocin-induced diabetes in the mouse in vivo and in vitro. Diabetologia 23 : 374-378

29. Tait SPC, Poje M, Rocic B, Ashcroft SJH (1983) Diabetogenic action of alloxan-like compounds: the effect of dehydrouramil hydrate hydrochloride on isolated islets of Langerhans of the rat. Diabetologia 25:360-364

30. Gandy SE, Buse MG, Sorenson JRF, Crouch RK (1983) Attenuation of streptozotocin diabetes with superoxide dismutase-like copper (II) (3,5-diisopropyl salicylate) $)_{2}$ in the rat. Diabetologia 24 : 437-440

31. Orci L, Malaisse W (1980) Hypothesis: single and chain release of insulin secretory granules is related to anionic transport at exocytotic sites. Diabetes 29: 943-944.

32. Somers G, Sener A, Devis G, Malaisse WJ (1980) The stimulus-secretion coupling of glucose-induced insulin release. Pfügers Archiv 388: 249-253

33. Osei K, Falks JM, Nelson KP, Stephens R (1984) Diabetogenic effect of pentamidine: in vitro and in vivo studies in a patient with malignant insulinoma. Am J Med 77: 41-46.

Received: 2 January 1985

and in revised form: 6 May 1985

Professor Ag. R.Assan

C.H.U.Bichat

46, rue H.Huchard

F-75018 Paris

France 